\title{
BIOLOGICAL NEMATICIDES ASSOCIATED WITH POULTRY LITTER IN THE CONTROL OF NEMATODES IN SOYBEAN AND SECOND CORN CROP ${ }^{1}$
}

\author{
TAYRLEN EDUARDO AMORIM ROSA ${ }^{2 *}$, JEAN CRAMENAK DE SOUZA ${ }^{2}$, WELLINGTON JOSÉ PEREIRA ${ }^{3}$, \\ JANAINA ALVES DE ALMEIDA MOREIRA ${ }^{4}$, FERNANDO GODINHO DE ARAÚJO $^{5}$
}

\begin{abstract}
Alternative management measures have been used to reduce nematode population levels in affected areas. In this perspective, the objective was to evaluate the efficiency of nematicides based on fungus and bacterium, associated with poultry litter applied via ground in the management of Pratylenchus brachyurus and Heterodera glycines in soybean and corn crops in succession. The experiment was conducted in the $2018 / 19$ growing season in the municipality of Ipameri- GO $\left(-17^{\circ} 34^{\prime} 55.58^{\prime \prime} \mathrm{S}-48^{\circ} 12^{\prime} 02.35^{\prime \prime} \mathrm{O}\right)$ in naturally infested field, arranged in a randomized block design, with 10 treatments and 4 replicates, being: T1 - Witness/ control, T2- Poultry litter, T3- P. lilacinum + T. harzianum, T4- B. subtilis + B. licheniformis, T5- $P$. chlamydosporia, T6- Abamectina, T7- P. lilacinum + T. harzianum + Poultry litter, T8- B. subtilis $+B$. licheniformis + Poultry litter, T9- P. chlamydosporia + Poultry litter, T10- Abamectina + Poultry litter. The poultry litter was added in the soil 10 days before planting. The plots were composed of 6 lines of $6 \mathrm{~m}$, with a spacing of $0.5 \mathrm{~m}$. In the soybean crop at 45 and 90 days after sowing (DAS), the fresh weight of the roots (MFR), nematological variables and productivity were evaluated. In corn, only nematological variables were evaluated at 60 DAS. The treatments using P. lilacinum $+T$. harzianum and B. subtillis $+B$. licheniformes increased the MFR and reduced the number of $P$. brachyurus and $H$. glycines at the root. P. chlamydosporia associated with poultry litter increased in productivity in soybean plants.
\end{abstract}

Keywords: Glycine max. Zea mays. Soybean Cyst nematode. Root lesion nematode. Biological control. Cultural control.

\section{NEMATICIDAS BIOLÓGICOS ASSOCIADOS A CAMA DE FRANGO NO CONTROLE DE NEMATOIDES NA SOJA E MILHO}

\begin{abstract}
RESUMO - Medidas alternativas de manejo têm sido utilizadas buscando reduzir níveis populacionais de nematoides em áreas afetadas. Nesta ótica, objetivou-se avaliar a eficiência de nematicidas biológicos a base de fungos e bactérias, associados a cama de aviário aplicada via solo no manejo de Pratylenchus brachyurus e Heterodera glycines na cultura da soja e milho em sucessão. O experimento foi conduzido na safra 2018/19 no município de Ipameri - GO (-17³4’55.58’S -48 12’02.35”O) em campo naturalmente infestado, disposto em delineamento de blocos casualizados, empregando 10 tratamentos e 4 repetições, sendo: T1- Testemunha, T2Cama de frango, T3- P. lilacinum + T. harzianum, T4- B. subtilis + B. licheniformis, T5- P. chlamydosporia, T6- Abamectina, T7- P. lilacinum + T. harzianum + Cama de frango, T8- B. subtilis + B. licheniformis + Cama de frango, T9- P. chlamydosporia + Cama de frango, T10- Abamectina + Cama de frango. A cama de frango foi adicionada ao solo 10 dias antes do plantio. As parcelas foram compostas por 6 linhas de $6 \mathrm{~m}$, com espaçamento de $0,5 \mathrm{~m}$. Na cultura da soja aos 45 e 90 dias após a semeadura (DAS) avaliou-se a massa fresca das raízes (MFR), variáveis nematológicas e produtividade. No milho avaliou-se apenas as variáveis nematológicas aos 60 DAS. Os tratamentos empregando P. lilacinum + T. harzianum e B. subtillis $+B$. licheniformes elevaram a MFR e reduziram o número de $P$. brachurus e $H$. glycines na raiz. $P$. chlamydosporia associada a cama de frango promoveram incremento de produtividade em plantas de soja.
\end{abstract}

Palavras-chave: Glycine max. Zea mays. Nematoide do cisto da soja. Nematoide das lesões radiculares. Controle biológico. Controle cultural.

\footnotetext{
${ }^{*}$ Corresponding author

${ }^{1}$ Received for publication in $05 / 05 / 2020$; accepted in 22/04/2021

Paper extracted from the dissertation masters of the first author.

${ }^{2}$ Program of Post-graduate in Plant Protection, Instituto Federal de Educação Ciência e Tecnologia Goiano, Urutaí, GO, Brazil; tayrlen@hotmail.com - ORCID: 0000-0003-1274-4229, jeancramenak@gmail.com - ORCID: 0000-0002-2921-9458.

${ }^{3}$ Agronomy College, Instituto Federal de Educação Ciência e Tecnologia Goiano, Urutaí, GO, Brazil; wellingtonjpereira74@gmail.com ORCID: 0000-0002-5897-636X.

${ }^{4}$ Program of Post-graduate in Agronomy, Universidade Federal de Goiás, Goiânia, GO, Brazil; janainaalmeida.agro@gmail.com - ORCID: 0000-0002-5876-0526.

${ }^{5}$ Department of Innovation, Instituto Federal de Educação Ciência e Tecnologia Goiano, Rio Verde, GO, Brazil; fernando.godinho@ifgoiano.edu.br-ORCID: 0000-0001-5217-4609.
} 


\section{INTRODUCTION}

In the Midwest and Northeast of Brazil, the cultivation of soybeans and corn in succession is widely practiced by farmers. About 100 species of nematodes, included in 50 genera, have been associated with soybean worldwide (DIAS et al., 2010). In Brazil, corn can be affected by 40 species, covering about 12 genera (MIRANDA; MIRANDA, 2018). The most important nematodes are: Meloidogyne incognita, M. javanica, Pratylenchus brachyurus and Heterodera glycines (CORTE et al., 2014).

In terms of commercial damage, it is estimated that the losses caused by nematodes exceed 80 billion dollars (FERRAZ; BROWN, 2016). According to Machado (2015), the economic damage faced by Brazil in the face of these pathogens can reach $\mathrm{R} \$ 35$ billion per agricultural year. It is believed that, of this amount only in the soybean crop, losses of R $\$ 16.2$ billion will occur.

Nematodes cause limitations in the absorption of water and mineral salts from the soil solution, reflecting a decrease in the root system and aerial part, wilted and / or chlorotic leaves, and consequently a reduction in productivity (DIAS et al., 2010). Alternative management measures have been used in order to reduce nematode populations, such as: use of chemical and biological nematicides, organic compounds, resistant plants or with low reproduction factor $(\mathrm{RF})$ and rotation with non-host crops (SILVA et al., 2018).

The use of nematicides via seed treatment or application in planting furrows is a technique that is widespread among farmers, due to the practicality of application (INOMOTO, 2011). In Brazil, there are five biological agents and six chemical molecules capable of controlling nematodes in soybeans and corn (Abamectin, Fluensulfone, Tiodicarb, Cadusafós, Fluopyram, Thiophanate-methyl + Fluazinam, Bacillus sp., Trichoderma harzianum, Pasteuria nishizawae, Purpureocillium oniachilporchyliachilia) (AGROFIT, 2020).

Nematophagous fungi such as Purpureocilum lilacinum and Pochonia chlamydosporia have the ability to suppress nematode reproduction by destroying the egg embryo, colonizing females and cyst (SILVA, 2015a). The fungus T. harzianum, in addition to acting on eggs and juveniles of nematodes, manages to activate plant defense mechanisms (LIMA, 2019). Likewise, some bacteria of the genus Bacillus sp. exert nematicidal action on early stages of nematodes by releasing antibiotic compounds, in addition to promoting the development of cultivated plants (SILVA, 2015b).

Pasteuria nishizawae is an obligatory and specific parasite bacterium of $H$. glycines. Its parasitism begins with the adherence of the endospores to the cuticle of second-stage juveniles, where the penetration of the germ tube into the nematode's body can prevent its penetration into the roots. Infected females and cysts are colonized by sporangia and mature endospores, which are released into the soil after the nematode disintegrates (VICENTE, 2014).

When poultry litter is added to the soil it releases toxic compounds to the nematodes (ammonia, humic and fulvic acids) during its decomposition process, provides nutrients to the plants and increases the organic matter content in the soil, favoring the development of antagonistic microorganisms (KOENNING et al., 2003). The interaction between poultry litter and biological control agents is promising, since two nematode control techniques are employed, decreases the use of chemicals and offers a purpose to an agroindustrial residue in a sustainable and environmentally safe way.

Therefore, the present study aimed to evaluate the efficiency of biological nematicides based on fungi and bacteria, associated with the poultry bed in the management of Pratylenchus brachyurus and Heterodera glycines in soybean and corn crops in succession.

\section{MATERIALS AND METHODS}

The assay was conducted in the 2018/19 harvest in the municipality of Ipameri-Go, located under the geographical coordinates $-17^{\circ} 34^{\prime} 55.58^{\prime \prime} \mathrm{S}$ $48^{\circ} 12^{\prime} 02.35^{\prime \prime} \mathrm{O}$, in a commercial area naturally infested with $P$. brachyurus and H.glycines race 6, in which the producer practices the cultivation of soy and corn in succession. The experiment was arranged in a randomized block design in a $5 \times 2$ factorial scheme, with 4 replications (Table 1).

Two plantings were carried out, first sowing soybean (Desafio RR) and then corn (AG8061 PRO2) in succession. The poultry litter was added to the soil ten days before sowing soybeans, in the amount of $4 \mathrm{Mg} \cdot \mathrm{ha}^{-1}$ according to preliminary dose studies. The nematicides were added to the soybean and corn seeds in a plastic bag previously identified, following the doses recommended in the package leaflet by the manufacturers. Planting took place shortly after seed treatment. Each experimental plot contained six planting lines six meters long, spaced $0.5 \mathrm{~m}$ apart, making up a useful area of $18 \mathrm{~m}^{2}$, where the $1^{\text {st }}$ and $6^{\text {th }}$ lines were considered as borders, in the $2^{\text {nd }}$ and $5^{\text {th }}$ lines soil and root collections were carried out, and at the $3^{\text {rd }}$ and $4^{\text {th }}$ were preserved to evaluate productivity.

The analysis of the initial nematode population in the soil, chemical analysis of the organic compost and soil fertility was performed (Table 2). Fertilization and other cultural treatments were carried out according to the standard of the producer, used during the crop cycle. Nematological evaluations $\left(P\right.$. brachyurus $/ 10 \mathrm{~g}$ of root and $100 \mathrm{~cm}^{3}$ 
of soil, females of $H$. glycines/g of root, viable and non-viable cyst per $100 \mathrm{~cm}^{3}$ of soil, eggs/female and eggs/cyst of $H$. glycines) and fresh root mass was carried out at 45 and 90 days after sowing (DAS) for soybean and at 60 DAS for corn. Yield was evaluated only at the end of the soybean crop (first crop).

Table 1. Treatments used in the experiment for the cultivation of soybean and safrinha corn.

\begin{tabular}{ccc}
\hline & Treatments & Doses* \\
\hline 1. & Control & - \\
2. & Poultry litter & $4^{* *}$ \\
3. & Purpureocilum lilacinum + Trichoderma harzianum & $30+15$ \\
4. & Bacillus subtilis + Bacillus licheniformis & $20+20$ \\
5. & Pochonia chlamydosporia & 56 \\
6. & Abamectina & 50 \\
7. & P. lilacinum + T. harzianum +Poultry litter & $30+15+4 * *$ \\
8. & B. subtilis + B. licheniformis + Poultry litter & $20+20+4^{* *}$ \\
9. & P. chlamydosporia +Poultry litter & $56+4^{* *}$ \\
10. & Abamectina + Poultry litter & $50+4^{* *}$ \\
\hline
\end{tabular}

*g i.a/100 kg of seeds.

**Mg.ha ${ }^{-1}$.

Table 2. Result of soil and poultry litter analysis, with the respective nutrient contents.

\begin{tabular}{|c|c|c|c|c|c|}
\hline \multicolumn{3}{|c|}{ Poultry litter } & \multicolumn{3}{|c|}{ Soil analysis } \\
\hline Nutrients & & Content & Components & & Content \\
\hline $\mathrm{K}_{2} \mathrm{O}$ & & 3.30 & Clay & & 550.4 \\
\hline $\mathrm{P}_{2} \mathrm{O}_{5}$ & & 2.38 & Silt & ---g/kg--- & 200 \\
\hline $\mathrm{N}$ & & 3.40 & Sand & & 249.6 \\
\hline $\mathrm{Ca}$ & $---\% 0^{---}$ & 2.21 & M.O & & 6.10 \\
\hline $\mathrm{Mg}$ & & 0.54 & V & & 72.26 \\
\hline $\mathrm{S}$ & & 0.77 & $\mathrm{P}$ & $m g / m^{3}$ & 0.506 \\
\hline $\mathrm{B}$ & & 55 & $\mathrm{~K}$ & $--\mathrm{mg} / \mathrm{dm}^{3}--$ & 232 \\
\hline $\mathrm{Cu}$ & & 108 & $\mathrm{Ca}$ & & 5.7 \\
\hline $\mathrm{Fe}$ & ---mg/kg--- & 364 & $\mathrm{Mg}$ & molo/dm 3 & 1.8 \\
\hline $\mathrm{Mn}$ & & 328 & $\mathrm{H}+\mathrm{Al}$ & $--\mathrm{cmolc} / \mathrm{dm}--$ & 3.1 \\
\hline $\mathrm{Zn}$ & & 310 & CTC & & 11.3 \\
\hline - & & - & $\mathrm{pH}$ & -- Water -- & 6.33 \\
\hline
\end{tabular}

The specimens of $P$. brachyurus were extracted from plant tissue using the method proposed by Coolen and D'Herde (1972) and from the soil by Jenkins (1964). The extraction of females and cyst were performed based on the methodology proposed by Tihohod (1993) and (ANDRADE; ASMUS; SILVA, 1995), respectively. Yield was evaluated when $95 \%$ of soybean plants reached full maturity (stage R8) with grains presenting about $15 \%$ moisture (OLIVEIRA JUNIOR et al., 2016). All plants were collected in $5 \mathrm{~m}$ from the two central lines of each plot for the evaluation.

Nematological and fresh root mass data were subjected to multivariate analysis of variance (MANOVA). From this, it was evaluated whether there was a multivariate difference between the treatments studied by means of the Pillai's Trace test, with a level of significance of $5 \%$. After evidencing a significant difference between treatments, canonical discriminating variables were constructed to visualize the behavior of treatments. This was done using the MANOVA residual variance and treatment matrices. The first two canonical discriminating variables were presented in a biplot chart and to identify significant differences between treatments, ellipses of $95 \%$ confidence were built for the mean scores of both (PILLAI, 1955; JOHNSON; WICHERN, 1999).

The productivity data were subjected to analysis of variance (ANOVA) and the treatment means were compared using Fisher's LSD test at 5\% significance level. The percentage of increase or decrease in productivity in relation to the control, was obtained from the calculation $\left(\frac{\text { Treatment }}{\text { Control }} \times 100\right)-100$. All statistical analyzes were performed using software R version 3.5.3 (R CORE TEAM, 2019).

\section{RESULTS AND DISCUSSION}

The result of the multivariate analysis of variance (MANOVA), analysis for the three periods analyzed in soybean and at 60 DAS in maize crop is shown in Table 3. 
The previous evaluation of the nematode population present in the area showed that the number of $P$. brachyurus and cysts of $H$. glycines were found to be elevated in the soil, both presenting the largest vectors in the graph (Figure 1). It is also noted that the behavior of the reliable ellipses remained very close and overlapping, which indicates a good distribution of the nematodes in the experimental area, allowing the conduction of the test on site.

Table 3. Result of multivariate analysis of variance (MANOVA) at 0, 45 and 90 DAS to soybean and 60 DAS to maize.

\begin{tabular}{|c|c|c|c|c|c|c|c|}
\hline \multirow{3}{*}{$\begin{array}{c}\text { Soybean } \\
0 \text { DAS }\end{array}$} & Variation source & Degrees of freedom & Pillai & $\begin{array}{c}\text { Approx } \\
\text { F num }\end{array}$ & Df & denDf & p-value \\
\hline & Treatment & 9 & 0.79989 & 1.2119 & 27 & 90 & 0.2475 \\
\hline & Residual & 30 & & & & & \\
\hline \multirow{3}{*}{$\begin{array}{l}\text { Soybean } \\
45 \text { DAS }\end{array}$} & Variation Source & Degrees of freedom & Pillai & $\begin{array}{l}\text { Approx } \\
\text { F num }\end{array}$ & Df & denDf & p-value \\
\hline & Treatment & 9 & 2.3761 & 1.0402 & 90 & 261 & 0.3987 \\
\hline & Residual & 30 & & & & & \\
\hline \multirow{3}{*}{$\begin{array}{l}\text { Soybean } \\
90 \text { DAS }\end{array}$} & Variation source & Degrees of freedom & Pillai & $\begin{array}{l}\text { Approx } \\
\text { F num }\end{array}$ & Df & denDf & p-value \\
\hline & Treatment & 9 & 2.5423 & 1.1417 & 90 & 261 & 0.2114 \\
\hline & Residual & 30 & & & & & \\
\hline \multirow{3}{*}{$\begin{array}{c}\text { Maize } \\
60 \text { DAS }\end{array}$} & Variation source & Degrees of freedom & Pillai & $\begin{array}{l}\text { Approx } \\
\text { F num }\end{array}$ & Df & denDf & p-value \\
\hline & Treatment & 9 & 2.5317 & 1.8886 & 63 & 210 & $<0.001$ \\
\hline & Residual & 30 & & & & & \\
\hline
\end{tabular}

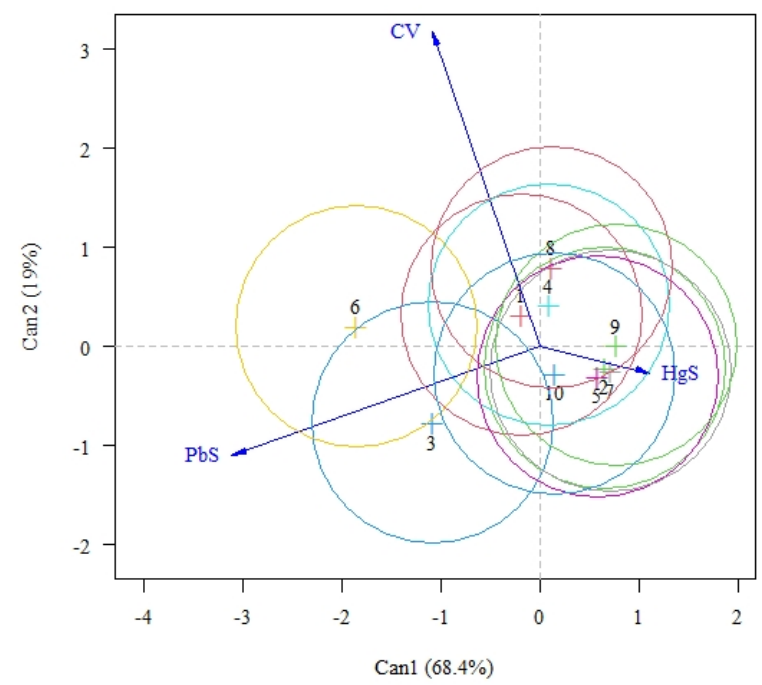

Figure 1. Biplot containing mean scores of canonical discriminating variables, under the effect of the initial population in the plots where the treatments were applied, with ellipses of $95 \%$ confidence, analyzed before the installation of the test. Pbs: P. brachyurus $/ 100 \mathrm{~cm}^{3}$ of soil, HgS: $H$. glycines $/ 100 \mathrm{~cm}^{3}$ of soil, CV: Viable cyst $/ 100 \mathrm{~cm}^{3}$ of soil. T1- Control, T2Poultry litter, T3- P. lilacinum $+T$. harzianum, T4- B. subtilis $+B$. licheniformis, T5- P. chlamydosporia, T6- Abamectina, T7- P. lilacinum + T. harzianum + Poultry litter, T8- B. subtilis + B. licheniformis + Poultry litter, T9- P. chlamydosporia + Poultry litter, T10- Abamectina + Poultry litter. 
At 45 days after sowing (DAS), the use of isolated chicken litter and the association of $P$. lilacinum and $T$. harzianum with the organic compound were the ones that came closest to the variable vector (MFR), when compared to the other treatments (Figure 2).

The variable $P$. brachyurus per $10 \mathrm{~g}$ of root $(\mathrm{PbR})$ was reduced by positioning the treatment with poultry litter associated with $P$. lilacinum and $T$. harzianum at 45 DAS. All treatments reduced the density of $P$. brachyurus in the root system in relation to the control. The use of poultry litter alone reduced the amount of females (FM) in the root system at $45 \mathrm{DAS}$; however, the combination of organic compound with Abamectin did not affect the number of females, viable and unviable cyst of $H$. glycines for the same observed time.

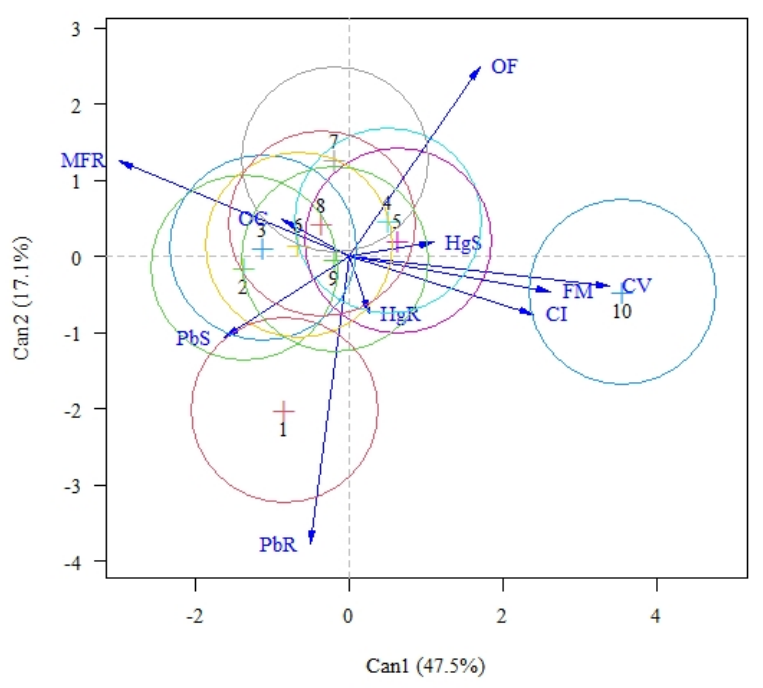

Figure 2. Biplot containing mean scores of canonical discriminating variables under the effect of 10 treatments with $95 \%$ confidence ellipses, for nematological assessment of soil and root at 45 days after sowing (DAS) in soybean. MFR: Fresh root mass, PbR: P. brachyurus $/ 10 \mathrm{~g}$ of root, Pbs: P. brachyurus $/ 100 \mathrm{~cm}^{3}$ of soil, FM: Female/g of root, HgR: Juvenile of $H$. glycines $/ 10 \mathrm{~g}$ of root, HgS: Juvenile of $H$. glycines $/ 100 \mathrm{~cm}^{3}$ of soil, CV: Viable cyst/100 $\mathrm{cm}^{3}$ of soil, CI: Unviable cyst $/ 100$ $\mathrm{cm}^{3}$ of soil, OF: Eggs/female, OC: Eggs/cyst. T1- control, T2 - poultry litter, T3- P. lilacinum + T. harzianum, T4- B. subtilis $+B$. licheniformis, T5- P. chlamydosporia, T6- Abamectina, T7- P. lilacinum + T. harzianum + poultry litter, T8- $B$. subtilis $+B$. licheniformis + poultry litter, T9- P. chlamydosporia + poultry litter, T10- Abamectin + poultry litter.

t 90 DAS it is possible to observe that Abamectin alone, $P$. lilacinum $+T$. harzianum and $B$. subtilis $+B$. licheniformis, both biological associated with poultry litter, showed better development in the root system of soybean plants and better efficacy in reducing $P$. brachyurus $(\mathrm{PbR})$ and $H$. glycines $(\mathrm{HgR})$ at the root, in relation to the positioning of biological agents in isolation (Figure 3). The use of Abamectin + poultry litter remained close to the female variables in the root (FM), viable cyst $(\mathrm{CV})$ and unviable (CI) of $H$. glycines in the soil, at 90 DAS.

The evaluated treatments did not differ statistically from the control in relation to the productivity of the soybean crop. However, the use of $P$. chlamydosporia alone presented an increase of $1 \%$ in relation to the control. When $P$. chlamydosporia was associated with chicken litter, it showed an even greater increase, with $8.8 \%$ in relation to soybean plants that did not receive treatment (Table 4).

In the cultivation of safrinha corn, it is possible to observe at 60 DAS that the association of
B. subtilis $+B$. licheniformis with poultry litter, the increase in (MFR) was superior to the treatment with B. subtilis $+B$. licheniformis isolated. The lowest number of $P$. brachyurus in the root $(\mathrm{PbR})$ was seen with the use of $P$. chlamydosporia, compared to the other treatments. Abamectin + poultry litter remained close to the vector of the viable $(\mathrm{CV})$ and non-viable (CI) variables of $H$. glycines in the soil (Figure 4).

The release of nutrients such as nitrogen, phosphorus and potassium, an increase in the content of organic matter and an improvement in the physical-chemical properties of the soil caused by the chicken litter, promoted better penetration and development of the root system in soybeans and corn. A study conducted by Scherer (1995) reveals that the fresh mass of corn roots that received fertilizer with poultry litter, were benefited due to the ability of poultry manure to increase the exchange of cations and the availability of nutrients for plants.Another factor that favored the increase in fresh mass of root plants, was the suppression of 
nematodes caused by the direct action of the poultry litter, through the release of ammonia and toxic humic acids to the nematodes and by the interaction with biological control agents through the indirect availability of organic carbon in the soil. In parallel to the results found in this work, Santos et al. (2019) observed that the treatment of soybean seeds with nematophagous fungi, in addition to promoting greater accumulation of fresh mass at the roots, reduced by up to $68.30 \%$ the number of $P$. brachyurus in the root system, in relation to the control.

In addition to the direct action on nematodes through the release of humic acids and toxic gases during the organic matter decomposition process, the availability of organic carbon in the soil may have favored the growth and establishment of the fungi $P$. lilacinum and T. harzianum and the bacteria of the genus Bacillus sp. This synergism possibly suppressed populations of $P$. brachurus and $H$. glycines in crops used at field level. Al-Hazmi et al. (2019) analyzing the effect of different concentrations of humic acid on populations of $M$. javanica, found that the exposure of eggs and juveniles (J2) to the highest concentration of the compound, inhibited hatching by up to $59.8 \%$ and promoted a mortality rate of $\mathrm{J} 2$ by $89.5 \%$, respectively. Confirming the nematostatic effect of the poultry litter found in this work.

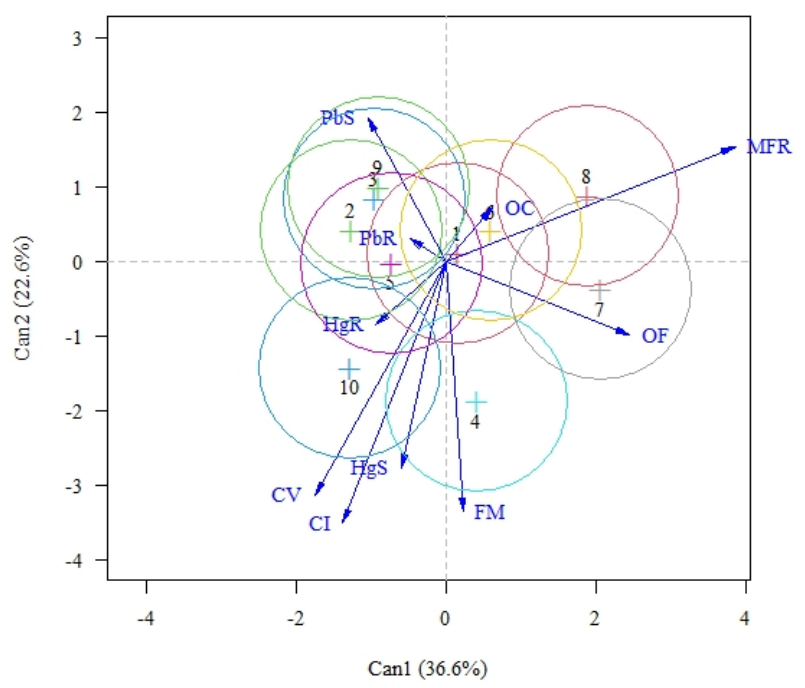

Figure 3. Biplot containing mean scores of canonical discriminating variables under the effect of 10 treatments with $95 \%$ confidence ellipses, for nematological assessment of soil and root at 90 days after sowing (DAS) of soybean. MFR: Fresh root mass, PbR: P. brachyurus $/ 10 \mathrm{~g}$ of root, Pbs: P. brachyurus $/ 100 \mathrm{~cm}^{3}$ of soil, FM: Female/g of root, $\mathrm{HgR}$ : Juvenile of $H$. glycines $/ 10 \mathrm{~g}$ of root, HgS: Juvenile of $H$. glycines $/ 100 \mathrm{~cm}^{3}$ of soil, CV: Viable cyst $/ 100 \mathrm{~cm}^{3}$ of soil, CI: Unviable cyst $/ 100$ $\mathrm{cm}^{3}$ of soil, OF: Eggs/female, OC: Eggs/cyst. T1- Control, T2- poultry litter, T3- P. lilacinum + T. harzianum, T4- B. subtilis + B. licheniformis, T5- P. chlamydosporia, T6- Abamectin, T7- P. lilacinum + T. harzianum + poultry litter, T8- B. subtilis + B. licheniformis + poultry litter, T9- P. chlamydosporia + poultry litter, T10- Abamectin + poultry litter.

Table 4. Effect of treatments on productivity $\left(\mathrm{kg} / \mathrm{ha}^{-1}\right)$ and percentage of increase in soybean plants.

\begin{tabular}{llcc}
\hline & \multicolumn{1}{c}{ Treatments } & $\begin{array}{c}\text { Productivity } \\
\left(\mathrm{kg} / \mathrm{ha}^{-1}\right)\end{array}$ & Increment/Reduction (\%) \\
\hline 1. & Control & $1952.0 \mathrm{ab}$ & 0 \\
2. & Poultry litter & $1853.7 \mathrm{ab}$ & -5.0 \\
3. & P. lilacinum + Trichoderma harzianum & $1812.3 \mathrm{ab}$ & -7.1 \\
4. & Bacillus subtilis + Bacillus licheniformis & $1725.3 \mathrm{ab}$ & -11.6 \\
5. & Pochonia chlamydosporia & $2062.7 \mathrm{~b}$ & 1.0 \\
6. & Abamectina & $1567.0 \mathrm{a}$ & -19.7 \\
7. & P. lilacinum + T. harzianum + poultry litter & $1564.5 \mathrm{a}$ & -19.8 \\
8. & B. subtilis + B. licheniformis + poultry litter & $1802.6 \mathrm{a}$ & -7.6 \\
9. & P. chlamydosporia + poultry litter & $2125.3 \mathrm{~b}$ & 8.8 \\
10. & Abamectina + poultry litter & $1735.9 \mathrm{ab}$ & -11.0 \\
\hline & CV (\%) & 18.46 & \\
\hline
\end{tabular}

Means followed by the same lower case letter in the column are not differentiated by the LSD test at 5\% significance. 


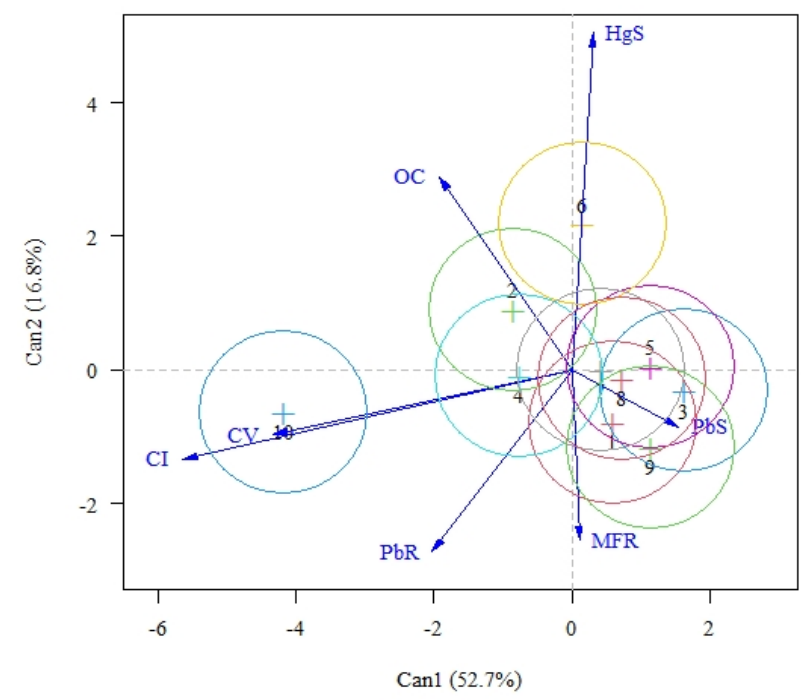

Figure 4. Biplot containing mean scores of canonical discriminating variables under the effect of 10 treatments with $95 \%$ confidence ellipses, for nematological assessment of soil and root at 60 days after sowing (DAS) of safrinha corn. MFR: Fresh root mass, PbR: P. brachyurus $/ 10 \mathrm{~g}$ of root, Pbs: P. brachyurus $/ 100 \mathrm{~cm}^{3}$ of soil, HgS: Juvenile of $H$. glycines $/ 100 \mathrm{~cm}^{3}$ of soil, CV: Viable cyst $/ 100 \mathrm{~cm}^{3}$ of soil, CI: unviable cyst/100 $\mathrm{cm}^{3}$ of soil, OC: eggs/cyst. T1- control, T2- poultry litter, T3 - P. lilacinum + T. harzianum, T4- B. subtilis + B. licheniformis, T5- P. chlamydosporia, T6- Abamectina, T7- P. lilacinum + T. harzianum + poultry litter, T8- B. subtilis + B. licheniformis + poultry litter, T9- P. chlamydosporia + poultry litter, T10- Abamectina + poultry litter.

Al-Hazmi et al. (2019) also analyzed the effect of humic acid associated with $T$. harzianum and $P$. lilacinum on reproduction and mortality of $\mathrm{J} 2$, and found that when the interaction between humic acid $+T$. harzianum and humic acid $+P$. lilacinum is made, hatching inhibition may occur in 80 and $85 \%$, respectively. Similarly, the population of $\mathrm{J} 2$ was suppressed in 74.6 and $78.1 \%$. In both tests, the percentages were higher when there was a longer time of direct exposure of the nematodes to the organic compound and to the biological agents. Lima et al. (2011) found the efficiency of poultry litter on females of $H$. glycines and attributed this control to the chemical substances released during the decomposition process of the organic compost, corroborating the results found in this study.

In protected environment conditions, DiasArieira et al. (2018) observed the effect of $T$. harzianum and $P$. lilacinum in the reduction of populations of $P$. brachyurus in soybean, where these fungi were potentiated when used together with an organomineral fertilizer. In the same study, the authors saw that the use of $P$. lilacinum $+T$. harzianum can reduce the number of $P$. brachyurus per $10 \mathrm{~g}$ of root by up to $61.2 \%$ in soy at 40 DAS and $47.2 \%$ at 60 DAS, under field conditions.

Cerqueira et al. (2015) researching the effects of $B$. subtillis microbiolization in common bean, found an increase in dry and fresh mass of the aerial part and fresh mass of root. Machado and Costa (2017) working with biocontrol of $P$. brachyurus in soybeans, observed in greenhouse conditions that $B$. subtilis provided efficiency above $70 \%$ in the control of $P$. brachyurus, when compared to the controls. Similar to previous research results, Oliveira et al. (2017) observed in bean plants at 30 DAS that treatment with $B$. subtilis via seed and spraying was equivalent to treatment with the chemical nematicide carbofuran.

Bacteria of the genus Bacillus sp. has the ability to colonize the rhizosphere of cultivated plants and produce antibiotic compounds (enzymes and toxins), forming a "protective film" on the roots, which interferes with plant and host recognition by nematode juveniles, reducing root penetration. In addition to causing disorientation in nematodes, bacteria of this genus, specifically $B$. subtilis and $B$. amyloliquefaciens, can induce systemic resistance in plants against phytopathogens and promote plant development through the release of volatile organic compounds (RYU et al., 2004; FARAG et al., 2013), thus explaining the better efficacy of bacteria when compared to fungi, in the control of P. brachyurus.

In relation to Abamectin + poultry litter, in addition to having efficiency compromised in the first days after sowing this experiment, the residual effect of the chemical nematicide is limited to the initial phase of the crop, allowing nematode population growth after this period. Similar to these results, Vitti (2009) did not observe the efficiency of abamectin on $H$. glycines at 60 days after sowing, only in the initial periods of development of soybean plants under field conditions.

The fungus $P$. chlamydosporia, in addition to affecting the reproduction of nematodes, has the ability to persist in the soil in adverse conditions and 
also to perform the solubilization of phosphorus in the soil, which promotes better development of the root system. These benefits can be correlated with the control efficiency exerted by the fungus on populations of $P$. brachurus in corn. Nunes et al. (2010), evaluating the efficacy of the fungus $P$. chlamydosporia in the control of $M$. incognita in soybeans, obtained effective control when the fungus was used via seed treatment, and application in postemergence of the crop. In parallel to this result, Nasu (2013) found that the use of $P$. chlamydosporia via seed treatment reduced population levels of $M$. incognita in soybeans and cotton in sandy and clayey soil, being the most efficient fungus in soil with greater porosity.

There are several factors that can influence the productivity of soybean plants in areas infested with nematodes, such as lack or excess of rain, soil fertility, population density, among others. According to Zavala-Gonzalez et al. (2015) and Monteiro (2013), P. chlamydosporia has the ability to stimulate plants to produce hormones important for plant development, as well as solubilizing phosphorus in the soil. Such factors, when provided in the initial development of plants, are fundamental to the yield of the crop.

In addition to the benefits promoted by $P$. chlamydosporia, the addition of poultry litter to the soil increases the availability of nutrients such as nitrogen, phosphorus and potassium for the cultivation of corn. Guerra et al. (2017) when developing a study with organic fertilization in the corn crop, found that plants that received $2 \mathrm{t} \mathrm{ha}^{-1}$ of poultry litter, expressed higher yield in relation to those that were not treated with organic compost. In this way, it is believed that the short period of time between the application of the soil poultry litter without mechanical incorporation and the sowing of soybeans, may have caused injuries to the roots due to the decomposition process of the organic material, causing a decline in productivity. In composting processes, carbon dioxide and water vapor are generated during the decomposition of organic substrates. In this process, the high microbiological activity reaches high intensity, causing an increase in temperature that can reach up to $65^{\circ} \mathrm{C}$ (PEREIRA NETO, 1987; KIEHL, 1998).

\section{CONCLUSION}

It was concluded that the use of $P$. lilacinum + T. harzianum and B. subtilis $+B$. licheniform is associated with the organic compost litter of chicken which promotes an increase in fresh root mass and decreases the number of nematodes in soybean and safrinha corn. The interaction of the fungus $P$. chlamydosporia with the organic compost promoted an increase in productivity. However, soybean sowing should be avoided soon after application (without mechanical incorporation) of poultry litter.

\section{REFERENCES}

AGROFIT. Sistema de Agrotóxicos Fitossanitários. Disponível em: <http://agrofit.agricultura.gov.br/ agrofit_cons/principal_agrofit_cons $>$. Acesso em: 18 mar. 2020 .

AL-HAZMI, A. S. et al. Effects of humic acid, Trichoderma harzianum, and Paecilomyces lilacinus on Meloidogyne javanica. International Journal of Agriculture environment and Bioresearch, 4: 6174, 2019.

ANDRADE, P. J. M.; ASMUS, G. L.; SILVA, J. F. V. Um novo sistema para detecção e contagem de cistos de Heterodera glycines recuperados de amostras de solo. Fitopatologia Brasileira, 20: 358358, 1995.

CERQUEIRA, W. F. et al. Influência de bactérias do gênero Bacillus sobre o crescimento do feijão comum (Phaseolus vulgaris L.). Enciclopédia Biosfera, 11: 82-82, 2015.

COOLEN, W.A.; D'HERDE, C.J. A method for the quantitative extraction of nematodes from plant tissue. State Nematology and Entomology Research Station, Ghent, 1972. 77 p.

CORTE, G. D. et al. Tecnologia de aplicação de agrotóxicos no controle de fitonematoides em soja. Ciência Rural, 44: 1534-1540, 2014.

DIAS, W. P. et al. Nematoides. In: ALMEIDA, A. M. R.; SEIXAS, C. D. S. Soja: doenças radiculares e de hastes e inter-relações com o manejo do solo e da cultura. Londrina, PR: Embrapa Soja. 2010. v. 1, cap. 13, p. 173-206.

DIAS-ARIEIRA, C. R. et al. Biological control of Pratylenchus brachyurus in soya bean crops. Journal of Phytopathology, 166: 1-7, 2018.

FARAG, M. A. et al. Chemical Communication between Plants and Bacteria through Airborne Signals: Induced Resistance by Bacterial Volatiles. Journal of Chemical Ecology, 39: 1007-1018, 2013.

FERRAZ, L. C. C. B.; BROWN, D. J. F. Nematologia de plantas: fundamentos e importância (Orgs). Manaus, AM: Norma Editora, 2016. 287-293 p.

GUERRA, A. M. N. M. et al. Avaliação da produtividade de grãos e de biomassa em dois híbridos de milho submetidos à duas condições de 
adubação no município de Santarém - PA. Revista Brasileira de Agropecuária Sustentável, 7: 20-27, 2017.

INOMOTO, M. M. et al. Efeito das densidades populacionais de Pratylenchus brachyurus no crescimento de plantas de algodão. Fitopatologia Brasileira, 26: 192-196, 2011.

JENKIS, W.R. A rapid centrifugal-flotation technique for separating nematodes from soil. Plant Disease Report, 48: 692-692, 1964.

JOHNSON, R. A.; WICHERN, D. W. Applied Multivariate statistical analysis, 4. ed., Rio de Janeiro: Prentice-Hall, s/v: 816, 1999.

KIEHL, E. J. Manual de Compostagem: maturação e qualidade do composto. Piracicaba, SP: Editora Ceres, 1998. 171 p.

KOENNING, S. R. et al. Effects of rate and time of application of poultry litter on Hoplolaimus Columbus on cotton. Plant Disease, 87: 1244-1249, 2003.

LIMA, D. F. Supressividade de Meloidogyne incognita em soja: interação entre milheto, urocloa, matéria orgânica ativada e Paecilomyces lilacinus. 2019. 64 f. Dissertação (Mestrado Profissional: Área de Concentração em Agroecologia) - Universidade Estadual de Maringá, Maringá, 2019.

LIMA, F. B. et al. Efeito da cama de frango na redução da população do Nematoide-de-cisto da soja. Nematologia Brasileira, 35: 71-77, 2011.

MACHADO, A. Nematoide: a praga que custa $\mathbf{R} \$$ 35 bilhões ao agronegócio brasileiro. Piracicaba: ADEALQ - USP-ESALQ. 2015. Disponível em: $<$ https://www.adealq.org.br/acontece/Nematoide-apraga-que-custa-R \$-35-bilh $\% \mathrm{C} 3 \% \mathrm{~B} 5$ es-aoagroneg\%C3\%B3cio-brasileiro-1410>. Acesso em: 27 jan. 2021

MACHADO, A. P.; COSTA, M. J. N. Biocontrole do fitonematoide Pratylenchus brachyurus in vitro e na soja em casa de vegetação por Bacillus subtilis.

Revista Biociências, 23: 83-94, 2017.

MIRANDA, L. L. D.; MIRANDA, I. D. Nematoides. 2018. Disponível em: <http:// www.nematoides.com.br/Content/

Fotos/3JULCartilhaNemat $\%$ C3\%

B3idesatualizada.compressed.pdf $>$. Acesso em: 18 mar. 2020.

MONTEIRO, T. S. A. Controle biológico do nematoide das galhas, Meloidogyne javanica, e promoção de crescimento vegetal com os fungos Pochonia chlamydosporia e Duddingtonia flagrans. 2013. 16 f. Dissertação (Mestrado), Universidade Federal de Viçosa, Viçosa, Minas Gerais, 2013.

NASU, E. G. C. Tratamento de sementes de soja e algodão com Pochonia chlamydosporia no controle de Meloidogyne incognita e histopatologia da inteiração tritrófica. 2013. 89 f. Tese (Doutorado em Fitopatologia: Área de Concentração em Fitopatologia) - Universidade Federal de Viçosa, Viçosa, 2013.

NUNES, H. T. et al. Uso de agentes microbianos e químico para o controle de Meloidogyne incognita em soja. Acta Scientiarum, 32: 403-409, 2010.

OLIVEIRA JUNIOR, A. et al. Estádios fenológicos e marcha de absorção de nutrientes da soja. Londrina, PR: Embrapa Soja, 2016. 1 f. (INFOTECA-E).

OLIVEIRA, G. R. F. et al. Influência do Bacillus subtilis no controle biológico de nematoides $\mathrm{e}$ aspectos produtivos do feijoeiro. Brazilian Journal of Biosystems Engineering, 11: 47-58, 2017.

PEREIRA NETO, J. T. "On the Tratment of Municipal Refuse and Sewage Sludge Using Aerated Static Pile Composting - A Low Cost Technology Aproach". University of Leeds, Inglaterra: $1987.839-845 \mathrm{p}$.

PILLAI, K. C. S. Some new test criteria in multivariate analysis. Annals of Mathematical Statistics, 26: 117-121, 1955.

R Core Team. R: A language and environment for statistical computing. R Foundation for Statistical Computing, Vienna, Austria, 2019.

RYU, C. M. et al. Bacterial Volatiles Induce Systemic Resistance in Arabidopsis. Plant Physiology, 134: 1017-1026, 2004.

SANTOS, A. R. B. et al. Biocontrole no manejo de Pratylenchus sp na soja. Revista de Ciências Agrárias, 42: 776-785, 2019.

SCHERER, E. E. Avaliação do esterco de aves e da uréia como fontes de nitrogênio para a cultura do milho. Revista Agropecuária Catarinense, 8: 15$18,1995$.

SILVA, J. O. Meloidogyne incognita na cultura do tomate: levantamento e manejo com produtos biológicos. 2015. 77 f. Dissertação (Mestrado em Agronomia: Área de Concentração em Agronomia), Universidade Federal de Goiás, Goiânia, 2015b. 
SILVA, R. A. et al. Efeito da rotação e sucessão de culturas no manejo de nematoides da soja em área arenosa. Nematropica, 48: 198-206, 2018.

SILVA, S. D. Avaliação da patogenicidade de isolados de Pochonia chlamydosporia e Purpureocillium lilacinum sobre ovos de Meloidogyne enterolobii. 2015. 108 f. Dissertação (Mestrado em Agronomia: Área de Concentração em Agronomia e Medicina Veterinária) - Faculdade de Agronomia e Medicina Veterinária, Brasília, 2015a.

TIHOHOD, D. Nematologia agrícola aplicada. Jaboticabal, SP: FUNEP, 1993. 372 p.

VICENTE, C. B. Ocorrência de Pasteuria nishizawae em áreas de soja e controle de Heterodera glycines em casa de vegetação. 2014. 49 f. Dissertação (Mestrado em Agronomia: Área de Concentração em Fitopatologia) - Universidade Federal de Uberlândia, Uberlândia, 2014.

VITTI, A. J. Tratamento de sementes de soja (Glycinemax (L.) Merr.) com abamectina, tiabendazol e acibenzolar-s-metil no manejo de nematoides. 2009. 39 f. Tese (Doutorado em Agronomia: Área de Concentração em Produção Vegetal) - Universidade Federal de Goiás, Goiânia, 2009.

ZAVALA-GONZALEZ, E. A. et al. Some isolates of the nematophagous fungus Pochonia chlamydosporia promote root growth and reduce flowering time of tomato. Annals of Applied Biology, 166: 472-483, 2015. 